\title{
Influence of Pension Insurance System in Colleges and Universities on Personnel Work and the Solutions
}

\author{
Shufeng $\mathrm{Ni}$ \\ Jilin Agricultural University \\ 512375850@qq.com
}

Keywords: Colleges and universities; Pension insurance system; Personnel work; Solution

\begin{abstract}
Since 2015, public institutions in China began to reform the pension insurance system, as a member of public institutions, colleges and universities are naturally influenced by the reform. The new pension insurance system has exerted certain influence on various aspects of colleges and universities, including the personnel work. This paper studies the journey of reforming pension insurance system in China and contents of the current pension insurance system, summarizes the influence of pension insurance system of personnel work in colleges and universities and proposed corresponding solution in the hope to improve personnel work at colleges and universities so as to make it more in conformity with the current pension insurance system at colleges and universities.
\end{abstract}

\section{Introduction to the Development of Pension Insurance System at Colleges and Universities}

Ever since it was born, China's college and university's pension insurance system has undergone a series of changes. Initially, college and university pension insurance is completely handled by the government and then colleges and universities themselves. It can be said that no matter what form of pension insurance system, it has singular level without high level of guarantee. However, the current college and university pension system has already been multi-level with high guarantee and changes towards being social. In summary, the changing progress of China's college and university pension insurance system can be divided into three stages:

The first stage is from the beginning of the late 1940s, was by the Chinese government is responsible for, unified by the handle, and workers in the work itself is not to need to pay endowment insurance, only need according to China promulgated the relevant retirement provisions in a certain period of time for retirement, so that you can in accordance with the provisions of monthly pension, this stage until 1980s until the end. The second phase started from the 80 s of the 20th century, this time, the personnel of pensions is no longer issued by the state, but is undertaken by the university itself, and some of the other costs is planning to society as a whole, this a continue to 2008. The third phase began in 2008 , in the same year, the Chinese government introduced the relevant policies about the old-age insurance system reform, but the beginning of the just in some provinces pilot. At that time, to choose the provinces and municipalities directly under the central government including Shanghai, Zhejiang, Guangdong, Chongqing, and other, new stage, endowment insurance is no longer simply by governments or units to bear, but individuals and government commitment to work together and after retired employees enjoy what kind of treatment, solely on the basis of in-service period to pay the endowment insurance to determine. In 2015, the Chinese government issued a series of policy, the reform of the old-age insurance system in the country began to implement, so the old-age insurance system at the present stage in the nationwide are accepted.

\section{Contents of New Pension Insurance System}

The current implementation of the colleges and universities across the country endowment insurance system is according to the State Council promulgated the "on the organs and institutions of staff pension insurance system reform decision", the policy is formally introduced in January 2015, October formally implemented, so as to determine the comprehensive reform of the old-age insurance system of our country institutions. In the policy, but also put forward the reform of 
endowment insurance system should follow the principle, that is comprehensive, grass-roots, multilayer, sustainability, and so on, and particularly emphasized the fairness and justice and multi levels, said should be according to the actual situation to keep adapting to mobility. The new endowment insurance system, the implementation of the final target is to set up a set of perfect social insurance system, the system should be independent of the organs and institutions, and has a variety of funding sources, security mode diversification, management and society of. In this "decision" also clearly pointed out that the pension system reform should be done "a unified" and "five simultaneous"'. The so-called "a unified" refers to the institutions and enterprises should unify, determined by the combination of social pooling and individual account of the basic old-age insurance system, both units or enterprises, should by the units or enterprises and individuals to pay to keep the old insurance, retirement benefits and pay endowment insurance directly linked together, so that we can to the greatest extent to avoid the problems caused by the "dual track". The so-called "five simultaneous" means: first, synchronous reform in institutions, so that you may not appear because of the reform of a business unit is not caused by the pension insurance system is not fair; second, occupation pension, basic pension insurance system simultaneously, can be avoided because the endowment insurance system the reform of the organs and institutions of staff treatment caused by the unfair situation in this case; third, the endowment insurance system reform and the reform of the wage system simultaneously, organs and institutions to improve the wages of the employees in a certain extent, and the organs and institutions of staff pay their own pension fund; fourth, to determine the treatment mechanism and adjusting mechanism of synchronous improvement; fifth the reform of the endowment insurance system, simultaneously in our country, so it can be avoided in different places because the implementation of the reform The contradictory phenomenon caused by different time.

\section{Significance of Reforming College and University Pension Insurance System}

As the Chinese government issues relevant policy regarding reforming the pension insurance system, colleges and universities nationwide have also reformed their pension insurance system, and such reform plays a very important role with very profound significance, which is mainly embodied in the following four aspects:

Conducive to Establish College and University Pension Insurance System. From the beginning of the 1970s, China has begun the implementation of the new endowment insurance system, the new endowment insurance system compared with the old pension insurance system, the biggest difference is a combination of the two parts of social pooling and individual contributions, and wider coverage, for enterprise employees and other employment groups, to participate in pension insurance, for residents who did not work, to participate in old-age insurance for urban and rural residents, thus changing the past only employees can enjoy the treatment of old-age insurance, greatly improve the coverage. However, the endowment insurance system just for enterprises and rural and urban residents made provisions, which does not relate to the workers and retirees, so the endowment insurance in the implementation did not related policies as the basis. In addition, for enterprise employees in urban and rural and urban residents, the after retirement, enjoy what kind of treatment is directly linked and pay endowment insurance, but for the employees, do not need to pay the endowment insurance of their own, so the turnover retired after treatment cannot be linked to the payment of expenses. This is unfair, very easy to cause the social turbulence, is not conducive to building a harmonious socialist society. With the reform of the endowment insurance system in Colleges and universities, it can be done as a whole.

Conducive to Solving Conflicts. Before reforming college and university pension insurance system, college and university employees, especially teachers, do not need to pay for the pension, but can enjoy high pension after retirement, which indicates the difference between their rights and obligations, and it can easily arouse social conflicts. With the reform of college and university pension insurance system, college and university have the same pension insurance system with enterprises so as to avoid this conflict.

Conducive to Demonstrating College and University Employees' Contribution. Before 
reforming pension insurance system at colleges and universities, how much pension college and university employees will get depends on their work period and is based on their basic salary before retirement. For example, if an employee's work period has reached 35 years, the pension is issued in the proportion of $90 \%$, and if the work period is only more than 10 years but has not reached 20 years, the pension is issued in the proportion of $70 \%$. It can be said that under this circumstance, pension of college and university employees is only related to their work period and not related to their actual contribution. In the new pension insurance system, distribution according to work is realized to a large extent, and college and university employees' pension is determined by how much pension they have paid and directly related to their contribution. The more they work, the more pension and salary they get after retirement.

Conducive to Promoting Comprehensive Reform of Colleges and Universities. Previously, there were great differences between the pension insurance system of colleges and universities and the pension insurance system adopted by enterprises so that for both enterprise staffs transferred to colleges and universities or college and university staffs transferred to enterprises, it is very difficult to transfer the pension relationship. Thus it can be said that under such background, it is hard to realize reasonable flow of talents and optimize the allocation. However, after colleges and universities adopt the same pension insurance system, there is no longer such difficulty, and it is easy to achieve reasonable talent flow, and in order to develop and retain talents, colleges and universities need to carry out comprehensive reform.

\section{Influence of Pension Insurance System Reform of Colleges and Universities on Personnel Work}

Influence of Pension Insurance System Reform of Colleges and Universities on Employment Mechanism. In order to implement the same pension insurance system at colleges and universities, college and university employees are divided into three categories: formal employees, personnel agency staff and temporary workers. For formal staffs, the pension insurance system of public institutes is adopted, and both personnel agency staffs and temporary workers participate in the corporate endowment insurance. For the teaching and administrative staff in Colleges and universities, the reform of the endowment insurance system can realize the free movement. Before the college old-age insurance system reform, colleges and university employees' pension completely relies on universities, if turnover, then you need to start from scratch. This is a very bad thing; but with the college old-age insurance system reform, university staff that choose to leave and there is no need to worry, the pension insurance relationship can be transferred accordingly, relying less on the unit.

Influence of Pension Insurance System Reform at Colleges and Universities on Retirement Mechanism. With the introduction of the new pension insurance system in colleges and universities, retirement mechanism at colleges and universities is also changed. In the past, for college and university employees, in order to retire, men must reach 60 years old, and women must reach 50 years old while the work period must exceed 10 years. After retirement, their retirement salary is directly connected with their last month's salary, and the issuing proportion is related to their work period, so for the retirement pension of many college and university teachers, they are most influenced by their salary before retirement and work period. Many college and university employees are unwilling to retire because after retirement, their salary is greatly reduced. However, with the reform of pension insurance system the retirement system is also changed to be less influenced by their salary level and work period, but is more associated with how much pension has been paid.

Influence of Pension Insurance System of Colleges and Universities on Three Kinds of Retired Personnel's Pension. Although there are regulations about the pension of three kinds of retired personnel in colleges and universities' pension insurance system, i.e., use "old method for previous employees, gradual transition for current employees and new method for new employees", there are still many problems in actual implementation, reducing the execution power of pension insurance system, unable to achieve the expected effects. 


\section{Measures to Solve the Influence of Colleges and Universities' Pension Insurance System on Personnel Work}

Establish New Employment System. In order to adapt to the college old-age insurance system reform, colleges and universities should also construct the new mechanism, so they can determine the position, select and appoint personnel according to the demands of the job to determine the required talents. After the talent selection, but also a reasonable use of people, this should optimize the position structure, not rigidly adhere to the traditional human resource management, but should explore the human resource management system to adapt to the university. Colleges and universities should be signed a contract with the staff, so that it can change the situation of the past fixed jobs, management can also be changed from identity management to post management, but also conducive to improving the enthusiasm of employees.

Improve the Retirement Mechanism. After reforming the pension insurance system, colleges and universities should also reform the retirement mechanism to make it more in accordance with the current situation. Before this, the retired salary of college employees is related to their last month's salary, so many teachers are unwilling to retire even they have reached the retirement age. New retirement system should link the employee retirement pension and the career of the income, so that even before retiring last month salary levels decreased, but if the wage level is relatively stable, then to finally enjoy the old-age insurance benefits nor too big impact; on the contrary, even if the increase in the wages of the last month, but also will not make the pension increase. In such a way that the pension will only related to the career of income, so to the certain age, university faculty will choose to retire.

Construction Retirement Benefits Connection Mechanism for Three Kinds of Retired Personnel. For old employees, use the old method, i.e., when the new pension insurance system is implemented, they have already retired, so they enjoy the pension according to the previous pension insurance system, and for the part of the subsidies, they can be paid by colleges and universities monthly or annually, and they can also be paid to the social insurance authority, which will manage and issue the insurance together. For current employees, gradually implement the system, i.e., when these employees began to work, the previous pension insurance system was adopted, so from the beginning of their workday to the day when the new pension insurance system was implemented, relevant fees have already been paid according to the new pension insurance system. For new employees, adopt the new method, i.e., when they began to work, the new pension insurance system was already implemented, then, relevant fees can be paid according to the latest regulation, and when they retire, they enjoy the basic pension and individual account pension.

\section{References}

[1] Jiang Sihua, Zhang Qing. Influence of Pension Insurance System at Colleges and Universities on Personnel Work and Solutions [J]. Science and Technology Entrepreneurship Monthly, 2015, 19:49-50.

[2] Song Dan. On Personnel File Management at Colleges and Universities in the Reform of Personnel System [J]. Human Resource Management, 2016, 02:167-168.

[3] Zeng Liping, Zhang Li. On the Reform of Pension Insurance System at Colleges and Universities [J]. Business Managers, 2016, 12:56.

[4] Chen Zeying, Hou Lisong. Review of Study into Pension Insurance System Reform at Colleges and Universities in China [J]. Research into Colleges and Universities in Heilongjiang, 2011, 02:89-92.

[5] Peng Yan, Liu Yuanhua. Problems in Current Reform of Pension Insurance System at Colleges and Universities in China [J]. Journal of Hengyang Normal College, 2011, 01:54-56.

[6] Research group of the Institute of Fiscal Science, Ministry of Finance, Su Ming, Yang Liangchu, Zhang Xiaoyun, Wang Ligang, Cheng Yu. Research into Pension Insurance System Reform at 
Public Institutes in China [J]. Economic Research Reference, 2012, 52:3-25.

[7] Liu Huipin. Exploration into Paths of Reforming Pension Insurance System at Colleges and Universities [J]. Theory Learning, 2010, 26:93-94.

[8] Ma Jinglin. Problems in Pension Insurance System at Colleges and Universities and Thoughts on Reform [J]. Network Wealth, 2010, 22:221-222.

[9] Jiang Fangxing. On the Reform of Pension Insurance System in Colleges and Universities in China [J]. Journal of Sichuan Vocational \& Technical College, 2013, 01:14-16.

[10] Shi Zhangyu. Research into Pension Insurance System Reform at Public Institutes and College Teachers' Expectation - Take the Example of Universities and Colleges in Xi' an [J]. Modern Marketing (the second half), 2016, 04:202-203. 